\title{
Russia in the liberal world order
}

\author{
Maxine David and Ruth Deyermond
}

Ideas about the nature of international order have been central to the contest between Russia and 'the West' in the twenty-first century and are fundamental to the relationship between Russia and the structures and states of the European Union (EU). The extent to which this order is, or should be, a liberal one is the source of much political and analytical debate in the EU-Russia landscape, as is the nature of the role of the United States (US) in both international and European politics and security. In the context of a more assertive Russian foreign policy, a rising China and a closer Sino-Russian relationship, and difficult Russia-US relations, the EU is increasingly entangled in the net of Russia's relations with others, especially the US. This chapter begins by considering the idea of a liberal world order (LWO), its origins, and some of the most significant debates about its character. Intimately connected to these debates are the issues of the LWO's Cold War origins and its relationship to US hegemony. It explores Russia's relationship to the LWO, and the ways in which that relationship is informed by Russian governmental concerns with US hegemony, or unipolarity. The chapter then considers the complex interrelationship of Russia, the LWO and Europe before concluding with some thoughts about possible futures.

\section{The liberal world order}

Although the origins of the LWO are located in the political thought and practice of the nineteenth century (Sørensen 2006; Ikenberry 2018: 13), the order to which the term refers is generally agreed to have emerged at the end of, and as a response to, the Second World War (Deudney and Ikenberry 1999; Ikenberry 2005; Kobayashi 2017). The creation of key LWO institutions, including the Bretton Woods institutions, the General Agreement on Tariffs and Trade (GATT, later the World Trade Organisation), and the European Economic Community occurred in the 1940s and 1950s, those institutions understood to be mechanisms both for preventing another world war and for rebuilding after the last one.

These institutions were created in the context of the Cold War, and most of them reflected the hegemonic position of the United States in relation to North America, Western Europe and East Asia. Nevertheless, scholars also recognise the building of the LWO was necessarily a joint effort, in which European and certain East Asian states were key to establishing its 
institutions, norms and practices, including free trade, alliances, multilateralism and the projection of democracy (Ikenberry 2005). The EU and its member states are therefore regarded as key actors in the LWO. The expansion of the LWO at the end of the Cold War was similarly tied to US hegemony, and to the global extension of that hegemony in the 1990s, during the US's 'unipolar moment'. This expansion was geographic, institutional and issue-related; it included the creation of new multilateral institutions and the further development of existing ones such as the EU, together with the emergence of more explicit and assertive practices and norms including democracy promotion and peacekeeping (notably including the Responsibility to Protect [R2P] doctrine).

The LWO has several features that distinguish it from other types of international order. One is the multiplicity of actors and actor types and thus the relative de-emphasis of states. As Kobayashi (2017), notes, the liberal perspective sees 'global governance as a shared practice of state and non-state actors, institutionalized by multilateral legal instruments, and maintained by shared aspirations of global community-building'. In evaluating the LWO, analysts consider the extent to which it offers what Ikenberry (2005) terms 'voice opportunities' to those at the regional and global levels, constituting, essentially, debates about power and representation. As such, international organisations and institutions form a crucial part of the order (Colgan and Keohane 2017: 37), as instruments for facilitating representation and cooperation and building trust between actors. The development of international law is a significant adjunct, providing the necessary regularity and reassurance for building trust and cooperation.

Although the LWO is characterised by a plurality of actor types, it is not characterised by normative pluralism. Liberal political and social values are, of course, central to the LWO. During the Cold War, this aspect of the US-led liberal order was understood by its members to distinguish it from the Soviet-led bloc; questions of democracy and human rights were central to the dominant discourse of 'the West' that identified the LWO as not only different from but superior to Communist opponents. The LWO was and remains associated with values that include freedom, justice, equality and transparency (Sørensen 2006). For Ikenberry, the pre-eminent theorist of the LWO, the liberal international order is founded on rules, defined by openness, 'organized around open markets, security alliances, multilateral cooperation, and democratic community' (Ikenberry 2005: 133). Thus, the LWO has twin foundations of economic liberalism and politics, especially democracy promotion and the protection of human rights.

If these are areas of general agreement among theorists of the LWO, there is disagreement among both scholars and actors about the interrelationship between the US-led liberal order and the broader post-Cold War order that transcended the limits of US hegemony. In particular, the relationship of the LWO to the United Nations (UN) is ambiguous - some UN structures, documents and practices appear to be the product of the same demands and norms that led to the creation of the LWO institutions, but the central role of the USSR, in particular, was also critical for its development. As discussed later, this matters because disputes about the character of the international order is one of the areas which has created friction between Russia and Western states in the twenty-first century.

The character of the LWO's liberalism is another issue contested by analysts and actors. One element of this debate concerns the use of institutions and accompanying rules to constrain actors - what Sørensen refers to as the Liberalism of Restraint (2006). The Liberalism of Restraint is matched, in Sørensen's understanding, by a Liberalism of Imposition, an 'activist' approach 'seeking to enforce a certain set of rules on the behaviour of member states' (Sørensen 2006: 261). Imposition has come also in the Western view that liberal democracy should be exported to those who do not have it, in its more extreme form through military interventions to change a regime (Kinacioğlu 2012). The 'saviour-complex' (the idea that weaker states 
might need to be 'saved' by stronger ones) and the democratic peace thesis inherent in the LWO have provoked discussions about sovereignty and imperialism (Chandler 2003; Duncombe and Dunne 2018; Sørensen 2006) and raised the question of whether the values (democracy, human rights etc.) inherent in an order such as the LWO could be successfully imposed or whether this constitutes an oxymoron. Analysts have also focused on the delegitimising effects on the LWO of so-called humanitarian interventions considering its roots in thinking on soft power (Chinkin 1999; Coady 2002). Russia is not the only space, therefore, to challenge this order.

\section{Russia and the liberal world order}

Russian governmental representations of the international order and Russia's position in it are grounded in an understanding of the character and evolution of the post-World War Two order that is significantly different from that of many Western governments and Liberal scholars. The liberal narrative has framed the post-1945 world order as one in which the hegemonic position of the US facilitated the creation of international institutions, multilateralism, economic development based on a capitalist model, and shared liberal norms. It represents the post-1989 order as a geographic expansion of, rather than a qualitative change in, that order. In contrast, the twentyfirst century Russian governmental narrative has characterised the post-1989 order as an increasingly destabilising departure from the order established after World War Two by states including the Soviet Union (Putin 2020), driven by US unipolarity and revisionism. In this understanding, the current world order is, or should be, a continuation of the post-1945 international settlement, one characterised by limited institutions (principally, the UN Security Council) in which inter-state relations operate within the framework of international law, grounded in the principle of state sovereignty, and in which pluralism of domestic political models is respected. It appears, then, that one of the problems at the heart of the disputes between Russia and liberal political elites and analysts in 'the West' over international order is a difference of understanding about the character of the order. The Russian view is of a thin post-1945 international order that has been distorted by US unipolarity; the Liberal Western view is of a thick liberal order constituted under conditions of US hegemony, that expanded after 1989, was originally accepted by the Russian government, but which the Russian government is now actively seeking to undermine.

This division in understanding and practice was not always evident. In the period immediately after the end of the Cold War, Russia appeared to many Western observers to have embraced the LWO. Russian admission into the economic structures of the LWO was an early and striking example of this. Russia joined the International Monetary Fund (IMF), the World Bank institutions and the newly created European Bank for Reconstruction and Development (EBRD) in 1992 and the G7 (or G8) in 1997; the Russian government sought admission to the WTO for several years, finally being admitted in 2012. Russia's joining of the Partnership for Peace (PfP) and the signing of the NATO-Russia Founding Act in 1997 appeared to indicate an acceptance of a US-led security order.

Beyond the membership of multilateral institutions, Russia in the early 1990s appeared to be in the process of normative alignment with the LWO, embracing a democratic political model and committing to human rights principles. Speaking at the United Nations Security Council (UNSC) in January 1992, for example, Boris Yeltsin declared that 'democracy is one of the major achievements of human civilisation', that 'our top priority is to guarantee all human rights and freedoms in their entirety, including political and civil rights', and that 'Russia regards the United States and the West not as mere partners but rather as allies' (United Nations Security Council 1992). As Forsberg has noted, 'liberal values were not imposed on Russia in the early 1990s; rather, Russians had embraced them by themselves' (Forsberg 2019: 164). 
A change in Russian governmental attitudes towards the LWO began to be noted by external observers and evident in governmental statements from the late 1990s, particularly in the context of the 1999 NATO intervention in Kosovo. NATO's actions brought about a shift, if not in Russia's foreign policy, at least in Russian perceptions of the West - what Lynch (2001) describes as 'stronger scepticism towards the West'. Gorodetsky (2003) portrayed Kosovo as a 'wake-up' call for the Kremlin, a view supported by the revisions made to the April 2000 Military Doctrine, with its emphasis on threats to Russian security. Baranovskii (1999) considered this recognition that Russia would suffer the same experiences as Serbia if it were not sufficiently strong. As would later be the case with the 2003 invasion of Iraq, the failure to obtain UNSC authorisation for the Kosovo intervention challenged the primacy of the body on matters of international peace and security and the importance of international law (David 2017). These concerns were extended and amplified by the assertively hegemonic foreign policy of the George W. Bush administration which combined a disregard for these key elements of the international order with a vigorous assertion of US dominance and the discursive promotion of democracy, including in the post-Soviet space, often in ways that appeared designed primarily to serve US national interests (Deyermond 2015).

As this suggests, the post-Cold War role of the US is central to understanding the contemporary Russian challenge to the LWO. Since the turn of the twenty-first century, Russia has consistently argued about the dangers of unilateralism, unipolarity, and US hegemony, a forceful voice against those who argued that the 'American system' could not be seen as imperial in nature given its negotiated character and institutional underpinnings (see Monaghan 2006). Further, Russia has been critical of the idea that American dominance was warranted by virtue both of the various types of protections that the US offers to others, as well as the fact that others contribute to the system itself (Ikenberry 2005: 137). Rather, for Russia, US power has come at the expense of the 'multilateral, rule-based order' (Ikenberry 2005: 135). The US's alleged aspirations towards unipolarity and the undermining of the UNSC, international law and the state sovereignty principle are represented as the principal threat to international order. The US's attack on state sovereignty is understood to come not only from the unlawful military action in Kosovo and Iraq but from an attempt to impose its own political model on other states. This, in Russian governmental representations, is an attack on pluralism in the international system and an authoritarian attempt to suppress the democracy of the international system in the name of liberal norms.

As policy documents, speeches and interviews demonstrate, this has been the dominant position of the Russian government on questions of international order since the mid-00s. Its most prominent articulation occurred in Putin's 2007 speech to the Munich Security Conference, in which he asked:

What is a unipolar world? However one might embellish this term, at the end of the day it refers to one type of situation, namely one centre of authority, one centre of force, one centre of decision-making. It is [sic] world in which there is one master, one sovereign. . . . And this certainly has nothing in common with democracy. . . Incidentally, Russia - we are constantly being taught about democracy. But for some reason those who teach us do not want to learn themselves.

(Putin 2007)

Similarly, in an article on Russian foreign policy, Putin identified the BRICs grouping as 'a striking symbol of the transition from a unipolar world to a more just world order' (Putin 2012). The 2016 Russian Foreign Policy Concept asserts as a Russian governmental priority the need 
to counter challenges to the primacy of international law, interference in states' internal affairs, and attempts at regime change by unnamed states - clearly the US and NATO allies (Russian Ministry of Foreign Affairs 2016).

The emergence of a more hostile position towards the LWO in the twenty-first century supports Clunan's (2018) arguments regarding Russia and the LWO. Clunan argues that Russia has supported a 'charter liberalism' variant of the LWO, grounded in 'nondiscriminatory multilateral institutions that have preserved great power peace' though a tolerance of plural political models and a state-centric approach (Clunan 2018: 46). The development of liberal humanist and economic neoliberalist elements in the LWO, which gave primacy to democracy and human rights principles at the expense of state sovereignty and international pluralism, have, she suggests, been the principal reasons for Russian opposition to the LWO as currently constituted.

Russian governmental understandings of the LWO in the twenty-first century appear to be shaped in multiple ways by perceptions of the US's role and intentions. They also appear to be informed by a Realist worldview, which frames the multilateralism and norms of the LWO as instruments of US national interests. This has significant implications for Russian governmental representations of, and interactions with, the European Union and its members.

\section{Russia, Europe and the LWO}

The Russian governmental understanding of the character of the LWO and its response to the liberal character of European states and institutions reflects a realist conception of international relations. The realist character of core elements of twenty-first-century Russian foreign policy has been widely noted by scholars (for example, Gunitsky and Tsygankov 2018; Kropatcheva 2012; Lynch 2001). One element of this realist approach has been the assumption that US dominance extends to include significant control over the international actions of allied LWO actors; another is the assumption that national interest motivations underpin actions that therefore only appear to be driven by those normative concerns that supposedly characterise the LWO. Both of these have been very significant for Russia's perceptions of the EU.

The challenge to core elements of the LWO in Russia's interaction with Europe is evident in several areas. The first is an apparent reluctance to recognise the genuinely multilateral character of European regional organisation. Multilateralism is, of course, fundamental to the constitution of the EU, but recognition of multilateral cooperation on the basis of state equality and shared identity, not hegemony, is inconsistent with a realist worldview. Although formally committed to developing relations with the EU, the Russian government has demonstrated a preference for bilateral engagement with key European states, particularly France and Germany (see David et al. 2013; Schmidt-Felzmann this volume). It is reflected in, for example, the annual report by prominent Russian international relations scholars from the Institute of World Economy and International Relations (IMEMO), which views Russian challenges in Europe in relation to France and Germany, not the EU as an institution (IMEMO 2020: 441).

A consequence of this realist focus on powerful states rather than institutions is an assumption that the EU operates primarily as a great power tool, and specifically as a mechanism for the assertion of US hegemony, even though the US is not a member of the EU. This is most commonly done by linking EU actions in the post-Soviet space to the US and often pairing it with NATO expansion. The 2016 Russian Foreign Policy concept, for example, identifies EU 'geopolitical expansion', together with that of NATO, as the primary cause of destabilisation of Russia-West relations (Russian Ministry of Foreign Affairs 2016: Article 61) - a formulation that implies a power politics agenda at odds with the EU's goals and practices. This framing of EU action can also be seen in governmental accounts of the start of the Ukraine crisis and helps 
to explain Russia's role in the ongoing Ukraine crisis. From this perspective, the EU's attempt to reach an Association Agreement with Ukraine in 2013 was understood as a mechanism by which the US asserted its influence to detach Ukraine from Russia, and the Euromaidan protests and the removal of the Yanukovych government were seen as the product of a Western attack on Russian regional interests and part of a wider strategy to alienate Russia from its neighbours. In a 2014 article on the Ukraine crisis, for example, Foreign Minister Lavrov claimed that the EU and the US 'have been trying to compel Ukraine to make a painful choice between east and west' and that

Western states, despite their repeated assurances to the contrary, have carried out successive waves of NATO enlargement. . . . The EU's Eastern Partnership programme is designed to bind the so-called focus states tightly to itself, shutting down the possibility of co-operation with Russia.

(Lavrov 2014)

This is a realist explanation filtered through what Morozov describes as the Russian government's 'conspirological worldview' (Morozov 2015: 27), in which 'there is always some secret centre from which any political action is directed' and in which, given 'its tendency to see the world as bipolar', this centre is identified in the West (Morozov 2015: 32).

This realist framing of the EU's organisation and purpose appears to inform Russian responses to other central elements of the LWO as it is manifested in Europe. Most significantly, perhaps, is the contest over liberal norms that has emerged, particularly in the last decade. As a normative actor that places democracy and human rights at the core of both its internal, member-state identity and its external relations, the EU is a manifestation of one of the central elements of the LWO: the importance of shared liberal political norms. Understood through the lens of state-centric Realpolitik, however, norms become a site of competition and a tool to advance great power interests. This perspective had been shaped by the 'colour revolutions', which have been understood by the Russian government as a mechanism by which the US advanced its national interests under the cover of support for democracy (Deyermond 2016; Wilson 2009). Subsequent norm promotion by the US and the EU in the Eurasian space has generally been treated as an aggressive act, designed to undermine Russian influence, and as behaviour requiring pushback. This has led to the development of 'normative rivalry' between Russia and the EU in the region (Dragneva and Wolczuk 2012). Others have made the compelling argument that in both Georgia and Ukraine, Russia has 'parodied' (Burai 2016) Western norms, in these cases the preventative aspect of R2P, 'decoupling it from its original context . . and applied it without any evidence of such crises' (ibid: 77).

While the effect of such parody and Russia's contestation of norms relating to humanitarian intervention generally is to insulate Russia from accusations of hypocrisy, it also serves to undermine an important normative doctrine ('concept' for Russia - see Baranovsky and Mateiko 2016) that was adopted by the UN General Assembly less than two decades ago. Indeed, deeper studies of Russian officials' attitudes to R2P are instructive, the cleaving to a 'restrictionist' (Baranovsky and Mateiko 2016: 50) position on R2P revealing the limits of Kremlin commitment to multilateralist approaches to problem-solving. Indeed, they suggest Russia engages in contestation over multilateralism itself (David 2019) and that what it really champions is multipolarity (see Makarychev and Morozov 2011). In 2006, Monaghan related Russian thenForeign Minister Ivanov's conception of multipolarity as 'emphasis[ing] a more positive form of multi-polarity, one that did not involve opposition, but sought to build a new architecture of international relations, one of collective responses to contemporary challenges' (2006: 993). At 
the current time, such an analysis would seem optimistic, the lines dividing multilateralism and multipolarity etched firmly, the EU on one side (European Union 2016), Russia on the other (Monaghan 2006).

\section{Dead or dying? The liberal world order}

The EU-Russia relationship has been, and will likely continue to be, shaped in significant ways by another critical aspect of the contemporary LWO - its apparent decline and perceptions of that decline. Debates about the decline of the LWO have proliferated in the last decade, particularly since the election of Donald Trump as US president in 2016. We can discern at least four categories of argumentation in the literature focused on the reasons for the decline of the LWO. Interrelated as they are, broadly speaking, they can be set under headings relating to: i) the exploitation of US hegemony, ii) the efficacy of international institutions, iii) identity and iv) a lack of sufficient active support.

The first, as noted previously, concerns the role of the US itself in the post-Cold War era. US hegemonic overreach, particularly during the period of the 'Global War on Terror', undermined the credibility of the US leadership of the LWO and thus of the LWO itself. Ikenberry argued in 2005 that 'the postwar rules and institutions . . . shared visions and communal binds that shaped and sustained this United States-led order appear to be eroding' (2005: 134); Duncombe and Dunne (2018) make similar arguments. Consistent with this is the Russian governmental view of the US as the author of its own and the LWO's decline, that the sustainability of cooperation was contingent on responsible behaviour by the hegemon and the absence of violence and conflict.

The majority of the arguments about the decline of the LWO relate to the second category. They revolve around the role of rules, regimes and the institutions built to defend them, about their capacity to deliver the promised benefits of prosperity and stability and to restrain power, especially that of the hegemon, with the UN a particular focus of analysis. The liberal bargain, in short, did not hold. These are precisely the arguments that Russia, under both Yeltsin and Putin, made in relation to the US's (and some European actors') liberal interventionist impulses, as the Kremlin discourse around the 1998-9 Kosovo Crisis testifies. Further, Russia's points about the importance of institutions with respect to upholding the rules and standards, of ensuring order, have been given substance in the post-intervention Iraqi and Libyan landscapes, although questions can indubitably be asked about Russia's own role in Syria. Sørensen (2006: 267) perhaps best captures the overarching debate on interventionism in his conclusion that a Liberalism of Imposition goes too far, while a Liberalism of Restraint does not go far enough. Until the Trump administration, the US and Russia sat on opposite sides of this conundrum, while the EU member states were divided, some of them unengaged in the debate altogether. It was of little surprise, therefore, that for a long time, Brussels did not deliver, and did not seem capable of delivering, a consistent message - as Weymouth and Henig (2001) demonstrate in relation to the NATO bombing of Belgrade in 1999 - although the EU's Global Strategy of 2016 (EUGS) and its attendant institutional (widely defined) structures have gone some way to remedying this. Nevertheless, in the Russian perception, there is little value in continuing cooperation at the multilateral level as long as international institutions are not capable of restraining the worst excesses of US behaviour - though this does not, of course, imply that the importance placed on the role of the UNSC by the Russian government has diminished.

In the economic sphere, the crisis of capitalism (Sørensen 2006) has undermined support for the neoliberal facet of the LWO, particularly at sub-state level, and has generated a return to the discourses of protectionism. The LWO is associated, as Ikenberry notes, with 'financial 
crises and rising economic inequality' (Ikenberry 2020: 135); strikingly, despite their radically different views of the desirability of a liberal international order, Mearsheimer also suggests that one reason for the failure of the LWO is 'rising income inequality' and 'recurring financial crises' (Mearsheimer 2019: 8). Such arguments have been particularly significant in the EU, as the 2008 financial crisis affected all EU member states but sowed deep divisions between the 'fiscally responsible' north and the 'fiscally irresponsible' south. The failure of the Transatlantic Trade and Investment Partnership (TTIP) in 2016, the proposed trade agreement between the EU and US, provoked substantial protest within the EU, with trade unions, NGOS and environmental groups uniting in their opposition - a sign, one might say, of the voice opportunities successfully at work in the LWO, except for the singular lack of deep acknowledgement on the EU's part regarding the reason for that opposition, such that some have spoken of the illiberal aspects of the LWO (Sørensen 2006).

Connected to all these problems is the problem of the democratically unsupported extension of power to multilateral institutions, which Colgan and Keohane term 'multilateral overreach' (2017: 42), and a resultant feeling among publics that their future was being decided by those outside their state - in other words, by those who had no claim to their allegiance. Like the crisis of the LWO's neoliberal economic model, this has undoubtedly created an environment in which populist authoritarianism could flourish (Peterson 2018). The failure of liberal states and institutions to be vigilant, to ensure that the presumed benefits of liberal world order did trickle down to ordinary citizens have created a situation whereby a range of actors, of which Russia is only one, have credible grounds to challenge the current configuration of the liberal world order and to demand change.

The third category concerns identity. Colgan and Keohane make a persuasive argument that the post-1989 loss of the communist 'other' in relation to which the LWO and its member states had constructed that order's (and their own) identity (2017: 40) account for the twenty-firstcentury rise of illiberalism and populism. The failure to uphold the social contract has undoubtedly further sown the ground for a return to nationalist thought and policies, as seen clearly in the US under Trump, and in the United Kingdom, Hungary and Poland. The so-called refugee crisis and migration issues have revealed unequivocally that significant numbers of people in some EU states and in the US have not met with equanimity the bringing together of different peoples, suggesting there are clear (yet just as clearly unanticipated) limits to the capacity of LWO states to meet and cooperate.

The final category of argumentation concerns leadership: the LWO is in decline because of the failure of its adherents to defend it or uphold it. This argument is most frequently directed towards the role of the LWO's hegemon, the US, and in particular to the radical change of approach by the Trump administration. Haass (2018), for example, suggests that

The weakening of the liberal world order is due, more than anything else, to the changed attitude of the US [under Trump]. . . . America's decision to abandon the role it has played for more than seven decades thus marks a turning point. The liberal world order cannot survive on its own, because others lack either the interest or the means to sustain it.

Ikenberry is even more blunt, arguing that 'the liberal world order is collapsing because its leading patrons, starting with the United States, have given up on it' (Ikenberry 2020: 133).

Although most contemporary discussion is focused on the Trump administration, criticism of US inaction predates it. Lieber (2016) notes the Obama administration's expectation that others would defend the liberal world order when the domestic policymaking environment tied the US's hands (Lieber 2016). Responsibility extends beyond the US, therefore. It is not 
at all clear that the EU, even today, has understood and made the argument to its peoples that the liberal world order is something that must be upheld and defended on a daily basis and in a multitude of spaces. Accusations that the US ceded the interventionist ground - especially in Syria - to Russia often miss the EU as an equally culpable target. The bombing of hospitals in Syria, the continued use of chemical weapons, the sacrificing of the Kurds - all of these have occurred despite international structures that either prohibit them and/or (should) make them morally reprehensible. Any householder knows, without maintenance, sometimes costly maintenance, structures crumble.

All of what is set out here is revealing of a loss of legitimacy for the LWO. The US, particularly, is seen as having undermined trust in the LWO through interventionism and the delegitimation of international law, something that was possible only in a context of unilateralism. At the same time, others have argued for more resilience and durability in the LWO than some acknowledge (Ikenberry 2018; Peterson 2018). Thus, analysis is divided between those asking whether we are witnessing a breakdown of or, less catastrophically, a thinning out of cooperation and trust in the LWO. All this suggests that those looking to Russia as the actor responsible for the decline of the LWO would be better served turning their ideas on culpability to those actors at the thick end of that order. That is not to deny, however, those challenges to the LWO Russia has mounted, not least in terms of pursuing the path of an alternative order.

\section{Conclusions: if not liberal, what type of order?}

Russia's relationship to the LWO is complex, informed by the Russian governmental realist worldview, the role of US hegemony, and a contested understanding of the relationship of liberalism to key elements of international order including state sovereignty and international law, and of the role of norms in that order.

In accepting the idea that Russia is a contester of norms, we should also not suggest that it contests all norms (Kurowska 2014). The Russian government recognises that Russia is a beneficiary of the economic elements of the liberal world order; through free trade and the WTO, it has access to more markets on more favourable terms (Clunan 2018). More broadly, its 'return to the world stage' was aided by features of the LWO, especially institutions and Russia's seat at many of them. Any evidence of challenge to that order should therefore be seen as consistent with its concerns about the dangers of US hegemony and unipolarity. However, given the role of the US in sustaining the liberal world order, the obvious question is whether Russia can challenge US hegemony without simultaneously challenging, even bringing down, those elements of LWO that are beneficial to it.

If there is evidence of a Russian governmental desire to undermine, or replace, the US-led LWO, there is no evidence that it rejects the structure of post-1945 international order more generally. The continued importance of the UN and the discursive attachment to principles of state sovereignty and international law are supplemented by a growing focus on multilateral institutions at a regional level. Importantly, however, these are not politically liberal institutions (members are not liberal democracies, and the institutions are not concerned with - indeed, often reject - liberal norms) and, reflecting the Russian governmental preoccupation with power and polarity, they are dominated by Russia, or Russia and China, in the case of the Shanghai Cooperation Organisation (SCO). This appears to be consistent with the claims of the current Foreign Minister Lavrov, who says Russia sees the future as reflecting 'processes aimed at boosting multipolarity and what we call a polycentric world order' (Lavrov in Shcherback 2019). In practice, Russia looks increasingly embedded in relations with those to its east and south and increasingly resistant to deepening relations with those to its west. 
Russian membership in European-centric multilateral organisations (the Council of Europe and the Organisation for Security and Cooperation in Europe) is increasingly outweighed by its membership of those grounded in Eurasia, Asia and beyond: the Eurasian Economic Union, the BRICS, the SCO and the Collective Security Treaty Organisation. However, these memberships have not replicated the thicker relations produced by LWO institutions, and there is little to suggest a strong adherence to the social contract aspects of the LWO. Nor is there evidence of Russia using its hegemonic position, grounded in its historical relations with other post-Soviet members, to the benefit of their combined societies, as advocates for continuing American leadership in a LWO have argued the US has done. Instead, the Eurasian regional organisations appear designed to achieve the three realist goals of maintaining regional dominance, balancing against the US and sustaining a relationship with China that both assists that balancing and checks further Chinese regional influence. Consistent with this realism, Russian ideas about desirable forms of international order appear to be shaped by an understanding of the 1945-89 order as thin and not grounded in the expansionist liberalism of the post-Cold War period. Given the central role of US hegemony and liberal principles in the founding of the post-1945 order, however, expectations of a thin-order devoid of both these elements may be misplaced. As the debates around the decline of the LWO during the Trump period suggest, the world after the LWO may not confer the economic benefits and legal protections necessary to the protection and advancement of Russian goals, including the great power status that is central to the Putin government's conceptions of Russian identity. Russian governmental approaches to the LWO may prove damaging not only for the future of a liberal international order and Russia-Europe relations but also for Russia itself.

\section{References}

Baranovskii, V. (1999) 'Russia's interests are too important', International Affairs (Moscow) 45(3): 4-14.

Baranovsky, V. and Mateiko, A. (2016) 'Responsibility to protect: Russia's approaches', The International Spectator 51(2): 46-69.

Burai, E. (2016) 'Parody as norm contestation: Russian normative justifications in Georgia and Ukraine and their implications for global norms', Global Society 30(1): 67-77, doi:10.1080/13600826.2015. 1092424

Chandler, D. (2003) 'Expanding the research agenda of human rights: reply to Bellamy', International Journal of Human Rights 7(1): 128-40.

Chinkin, C.M. (1999) 'Kosovo: a “good” or "bad' war', American Journal of International Law 3(4): 841-7.

Clunan, A.L. (2018) 'Russia and the liberal world order', Ethics E International Affairs 32(1): 45-59.

Coady, C. (2002) 'The Ethics of Armed Humanitarian Intervention', United States Institute for Peace: Peaceworks, No 45, available at www.usip.org/sites/default/files/pwks45.pdf (accessed 15 May 2019).

Colgan, J.D. and Keohane, R.O. (2017) 'The liberal order is rigged: fix it now or watch it wither', Foreign Affairs 96(36): 36-44.

David, M. (2017) Russia's Challenge to US Hegemony and the Implications for Europe, in Salvador Santino F. Regilme and James Parisot (eds.), American Hegemony and the Rise of Emerging Powers. Cooperation or Conflict, London and New York: Routledge, pp. 198-215.

David, M. (2019) 'Whose Multilateralism? EU-Russia Relations in the Diminished World Order', Carnegie Moscow Center, 29.11.2019, available at https://carnegie.ru/commentary/80454 (accessed 4 December 2019).

David, M., Gower, J. and Haukkala, H. (eds.) (2013) National Perspectives on Russia, Abingdon: Routledge.

Deudney, D. and Ikenberry, G.J. (1999) 'The nature and sources of liberal international order', Review of International Studies 25: 179-96.

Deyermond, R. (2015) 'Disputed democracy: the instrumentalisation of the concept of democracy in US-Russia relations during the George W. Bush and Putin presidencies', Comillas Journal of International Relations 3: 28-43. 
Deyermond, R. (2016) 'The uses of sovereignty in twenty-first century Russian foreign policy', EuropeAsia Studies 68(6): 957-84.

Dragneva, R. and Wolczuk, K. (2012) 'Russia, the Eurasian Customs Union and the EU: Cooperation, Stagnation or Rivalry?', Chatham House Briefing Paper 2012/01.

Duncombe, C. and Dunne, T. (2018) 'After liberal world order', International Affairs 94(1): 25-42.

European Union (2016) 'Shared vision, common action: a stronger Europe. A global strategy for the European Union's foreign and security policy', June, available at https://europa.eu/globalstrategy/sites/ globalstrategy/files/regions/files/eugs_review_web_0.pdf (accessed 11 September 2019).

Forsberg, T. (2019) 'Russia and the European security order revisited: from the congress of Vienna to the post-cold war', European Politics and Society 20(2): 154-71.

Gorodetsky, Gabriel (ed.) (2003) Russia between East and West. Russian Foreign Policy on the Threshold of the Twenty First-Century. London: Routledge.

Gunitsky, S. and Tsygankov, A.P. (2018) 'The Wilsonian bias in the study of Russian foreign policy', Problems of Post-Communism 65(6): 385-93.

Haass, R.N. (2018) 'Liberal World Order, R.I.P', Council on Foreign Relations. March 21, available at www.cfr.org/article/liberal-world-order-rip (accessed 20 November 2019).

Ikenberry, G.J. (2005) 'Power and liberal order: America's postwar world order in transition', International Relations of the Asia-Pacific 5: 133-52, doi:10.1093/irap/lci112

Ikenberry, G.J. (2018) 'The end of liberal international order?', International Affairs 94(1): 7-23.

Ikenberry, G.J. (2020) 'The next liberal order: the age of contagion demands more internationalism, not less', Foreign Affairs 99(4): 133-41.

Institute of World Economy and International Relations (IMEMO) (2020) 'Russia and the world: 2020 IMEMO forecast', New Perspectives 28(4): 435-61.

Kinacioğlu, M. (2012) 'Forcing democracy: is military intervention for regime change permissible?', All Azimuth 1(1): 28-48.

Kobayashi, K. (2017) 'Whose global governance? Explaining the evolution of Russia's approach to global governance, 1945-2016', Rising Powers Quarterly 2(1): 183-209.

Kropatcheva, E. (2012) 'Russian foreign policy in the realm of European security through the lens of neoclassical realism', Journal of Eurasian Studies 3: 30-40.

Kurowska, X. (2014) 'Multipolarity as resistance to liberal norms: Russia's position on responsibility to protect', Conflict, Security \& Development 14(4): 489-508.

Lavrov, S. (2014) 'It's Not Russia That Is Destabilising Ukraine', The Guardian, 7 April, available at www. theguardian.com/commentisfree/2014/apr/07/sergei-lavrov-russia-stabilise-ukraine-west

Lieber, R.J. (2016) Retreat and Its Consequences: American Foreign Policy and the Problem of World Order, Cambridge: Cambridge University Press.

Lynch, A. (2001) 'The realism of Russia’s foreign policy', Europe-Asia Studies 53(1): 7-31.

Makarychev, A. and Morozov, V. (2011) 'Multilateralism, multipolarity, and beyond: a menu of Russia's policy strategies', Global Governance 17(3): 353-73.

Mearsheimer, J.J. (2019) 'Bound to fail: the rise and fall of the liberal international order', International Affairs 43(4): 7-50.

Monaghan, A. (2006) 'Calmly critical': evolving Russian views of US hegemony', Journal of Strategic Studies 29(6): 987-1013.

Morozov, V. (2015) 'Aimed for the better, ended up with the worst: Russia and international order', Journal on Baltic Security 1(1): 26-33.

Peterson, J. (2018) 'Present at the destruction? The liberal order in the Trump era', The International Spectator 53(1): 28-44.

Putin, V. (2007) 'Speech at the Munich Security Conference', 10 February, available at http://en.kremlin. ru/events/president/transcripts/24034 (accessed 20 November 2019).

Putin, V. (2012) 'Russia and the Changing World', 27 February, available at https://rusemb.org.uk/ press/612 (accessed 20 November 2019).

Putin, V. (2020) 75-ya sessiya General'noi Assamblei OON, available at http://kremlin.ru/events/president/ transcripts/64074 (accessed 20 November 2019).

Russian Ministry of Foreign Affairs (2016) 'Kontseptiya vneshnei politiki Rossiiskoi Federatsii', Russian Ministry of Foreign Affairs.

Shcherbak, A. (2019) 'Russian Liberal Model Is Losing Attractiveness, Lavrov Believes', TASS Russian News Agency, 12 April, 2019, available at tass.com/world/1053401 (accessed 20 August 2019). 


\section{Maxine David and Ruth Deyermond}

Sørensen, G. (2006) 'Liberalism of restraint and liberalism of imposition: liberal values and world order in the new millennium', International Relations 20(3): 251-72.

United Nations Security Council (1992) Provisional Verbatim Record of the Three Thousand and Forty Sixth Meeting, 31 January. S/PV.3046, available at undocs.org/en/S/PV.3046 (accessed 13 December 2019).

Weymouth, A. and Henig, S. (eds.) (2001) The Kosovo Crisis. The Last American War in Europe?, London: Pearson Education.

Wilson, J.L. (2009) 'Coloured revolutions: the view from Moscow and Beijing', Journal of Communist Studies and Transition Politics 25(2-3): 369-95. 